\title{
Assessing the Effects of Indiscriminate Disposal of Waste: A Case Study of the Keta Lagoon in the Volta Region of Ghana
}

\section{Sanusi Ahmed ${ }^{1}$ and Sarfo Isaac ${ }^{2}$}

${ }^{1}$ Department of Environment and Development Studies, Central University, Ghana

${ }^{2}$ The Graduate School, Nha Trang University, Vietnam

*Corresponding author: Isaac S, The Graduate School, Nha Trang University, Vietnam Tel: (+84)1223812106; E-mail: sarfo.power@gmail.com

Received date: September 16, 2016; Accepted date: October 24, 2016; Published date: October 31, 2016

Copyright: (C) 2016 Ahmed S, et al. This is an open-access article distributed under the terms of the Creative Commons Attribution License, which permits unrestricted use, distribution and reproduction in any medium, provided the original author and source are credited.

\begin{abstract}
Over the years, the issue of waste generation and management have been a major issue of concern, stemming a number of countries around the world, thus, developing countries. The ultimate aim of this study was to investigate into the effects of indiscriminate disposal of waste in and around the Keta Lagoon in the Volta region of Ghana. The study highlighted quite a number of respondents, who had lived in the area for quite a lengthy period and had observed the changes with regards to rapid deteriorating conditions of sanitation in the area as well as the aesthetic nature of the lagoon per the value it served decades ago and now. It is for these reasons why the study sought to look at what had contributed to the diminishing state of the Keta Lagoon, which is a designated Ramsar site (Ramsar Convention, 1971), hence, its importance to Ghana as a nation. The absence of waste management services, ignorance and lack of law enforcement units were identified as key factors, playing a fundamental role to indiscriminate dumping of refuse in and around the Keta Lagoon.
\end{abstract}

Based on key findings, recommendations on sensitising or educating the inhabitants as well as the general public on sanitation in basic schools would create some level of awareness. Strengthening and equipping the Municipal Assembly in the area by the government would help ensure frequent monitoring and regulate waste management in the area.

Keywords: Keta Lagoon; Management; Wetlands; Waste; Sanitation

\section{Introduction}

The problems of waste generation and management in most cities especially in developing countries have become one of the intractable environmental problems. This situation could be attributed to the low level of technology to handle the high rate of waste generation (Baum et al.) [1]. The Keta lagoon designated as a Ramsar site of international importance served as a huge resource for people in the area and the country, Ghana, at large several decades ago. It served as a good and conducive environment for several aquatic species and contributed immensely to the socio-economic welfare of the people through employment and recreation [2]. Recent development in the area shows that, this asset is faced with human induced factors, which is derailing its value (FAO, 2014).

The aesthetic nature of the Keta Lagoon and its surrounding environment is gradually diminishing with regards to its beauty and natural functions to indiscriminate dumping of waste (Ghana Environmental Protection Agency, 2004) [3]. The continuous dumping of refuse and open defecation has resulted in bad odour and the attraction of unwanted insects such as flies and mosquitoes to the environment. Prolonged dumping of both household and nonhousehold solid wastes around the lagoon could lead to severe sanitation problems with increased risks of the spread of diseases such as cholera, malaria and typhoid among residents in the area. It is therefore important to find out the environmental and social impacts of refuse dumping around the Keta Lagoon on the residents within the study area and the general environment. The study will also contribute to knowledge in environmental management in the Keta Municipality as well as help future scholars or researchers to build upon this study.

\section{General objectives of the study}

The study tends to delve into the following objectives. It is mainly to: Identify the types of waste dumped in and around the Keta Lagoon.

Examine the environmental and socio-economic impacts of indiscriminate dumping of waste in and around the Lagoon and its immediate environs.

Propose measures to help mitigate or regulate the problems identified in the selected area of study.

\section{Materials and Methods}

This section presents the methodology used for this study. It discusses how the field work was conducted, the research design used, the population of the study, data sources, research instruments, sampling methods, sampling size, and the data analysis techniques used.

\section{Location and brief history of the study area}

The Keta Municipal Assembly (KeMA) is one of the 25 administrative districts in the Volta Region of Ghana with Keta as it capital [4]. It was first carved out from the then Anlo District by Legislative instrument, L.I. 1475 in 1989 and later replaced by L.I. 1868 in 2007 as a municipality. Keta is located east of the Volta estuary, 
about $160 \mathrm{~km}$ to the east of Accra, and a population of 9,873(Keta Municipal Assembly, 2015). It shares common borders with the Akatsi District to the north, Ketu North District to the north-east and Ketu South District to the east, South Tongu District to the west and the Gulf of Guinea to the south (Figure 1). Out of the total surface area of 1,086 square kilometres, approximately $362 \mathrm{~km}$ square (about $30 \%$ ) is covered by water bodies as illustrated in Figure 1.

The Keta Lagoon is the largest of the over 90 lagoons that cover the $550 \mathrm{~km}$ stretch of the coastline of Ghana (Ghana Environmental Protection Agency, 2004). It is located in the eastern coast of Ghana with a coordinate of longitude $5^{\circ} 55^{\prime} 3.923^{\prime \prime} \mathrm{N}$ and latitude $0^{\circ} 59^{\prime} 20.503$ " E (Figure 1). It is separated from the Gulf of Guinea by a narrow strip of sandbar. This open salty water is surrounded by flood plains and mangrove swamps. Together they form the Keta Lagoon Ramsar site which covers $1200 \mathrm{~km}$ square. This Lagoon got its name and prominence from the settlement of Anlo- Ewes but more especially from the Keta town (Akyeampong) [5].

\section{The study area}

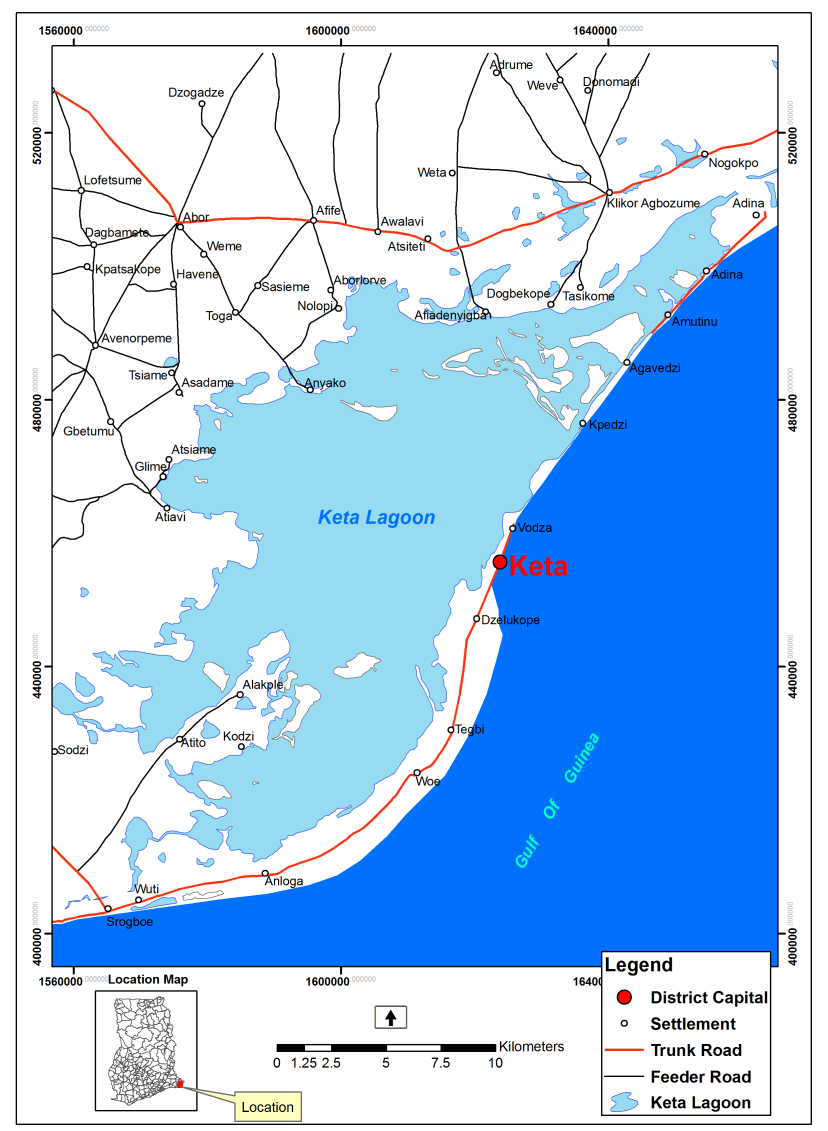

Figure 1: Map of Keta Municipality showing the Keta Lagoon, major roads and settlements. (Source: Central University, GIS laboratory).

\section{Research strategy}

The strategy used for conducting this research was through a qualitative approach with quantitative tools used in analysing data.
Most elements used in the collection of data for this study were strictly qualitative as it tends to delve into the social settings of man. The study also adapted to descriptive and participatory or action based research since individuals or people were involved through conducting of informal interviews and questionnaires being administered. Quantitative tools like; Microsoft excel sheet were used for the formulation of tables and charts but did not use rigid or laboratory approach to establish its findings.

\section{Research design}

The design for this study was basically a case study design. The research design used for this study was a single case study at the Keta Lagoon in the Volta region of Ghana. Abramson (1992) in his paper case for case studies, termed this type of research design is used to collect data from respondents who are believed to be a representation of a population, in a specific geographical area, over a period of time using some research instruments. Interview and questionnaire administration were used in conducting this study. A case study design was used because it facilitated the gathering of relevant information to meet the objectives of the study and the area in question.

\section{Population size}

The population of the Keta Municipality as of 2015 census carried out, was 167,015 (Keta Municipal Assembly, 2015). However, the direct population considered for the study are the residents, who live in the Keta town, because the study is limited to only the Keta.

\section{Sample size and sampling procedure}

Convenient sampling and purposive sampling techniques were employed in drawing the sample population for the study. A total number of hundred (100) residents were sampled out of the entire population that live close to the Keta Lagoon to constitute the respondents of the study. This sample size was considered appropriate for the study, since it represents a fair size of the resident around the lagoon. The time limit for the completion of the study was so short that it was not possible to choose a larger sample of the population. Purposive sampling technique was used in selecting residents who have their houses close to the lagoon. Convenience sampling was also used because only available and willing residents had questionnaires being administered to. The sampled respondents were deemed to have the required information relevant to answering the objectives of this study. Purposive sampling technique was also used in selecting five (5) staff members of the Keta Municipal Assembly (KeMA) for an interview [4].

\section{Mode of data collection}

Both primary and secondary data sources were used for the study. Secondary data for this study were collected from the Keta Municipal Assembly (KeMA), which entailed relevant documents needed to answer the objectives of this study. In addition, articles, journals, textbooks and other relevant information from the internet were also used [4].

Primary data were the first hand information collected during the course of the study. The primary data of this research were collected through the questionnaires administered to local inhabitants as well as interviews conducted during the collection of data for the study. 


\section{Data analysis}

Quantitative analysis of the data collected from the field survey was done, using SPSS software. The results were presented graphically in the form of tables, graphs and charts for easy interpretation. Descriptive (qualitative) analysis, which is a non-statistical analysing technique, was also used in analysing the collated information from the interviews and the questionnaires that were administered.

\section{Limitation of the study}

During the collection of data, some challenges were encountered and to some extent may limit the credibility of the information presented in this study. Some of these challenges were; some respondents not willing to give out information mainly perceiving it as a waste of time since some other researchers from ministries, academic institutions and so on some to interview them from time to time and yet have seen no changes in the area. Some were in a haste to answer questionnaires being administered unto them and hence, may to some extent not give out the right information. Also, some personnel at the Keta Municipal Assembly were not willing to give detailed information to delve into more areas but the ones relevant to the objectives were being obtained. In addition, this research adapted a single case study design and hence, findings cannot be generalised for other RAMSAR sites or towns with lagoons in other parts of Ghana. These challenges are minimal and do not limit the validity of this research.

\section{Result and Discussion}

\section{Bio data of residents}

Gender representation per data collected shows that majority of the respondents, $55 \%$ were males, while $45 \%$ were females. The results show that majority of the residents living close to the Keta Lagoon are males. Through the questionnaires administered, respondents indicated and affirmed the indiscriminate disposal of waste in and around the Lagoon as well as overfishing in the Lagoon.

The duration or length of stay was deemed relevant to the study since per the questionnaires administered, $10 \%$ of the respondents claim they had lived in the area for less than a year. $16 \%$ also claimed to have lived in the area between 1 and 5 years. $20 \%$ claim to have been there between 6 and 10 years where 54\% claim to have lived in the area over 10 years and hence, had ample knowledge and some of the issues which stems the area and hence, were deemed appropriate to help answer some of these research questions meant to answer the objectives of this study.

Hundred (100) sets of questionnaires were administered to respondents to assess the views of respondents on the indiscriminate dumping of refuse in and around the Keta Lagoon. Out of the total, $70 \%$ were related to the dumping of refuse and $30 \%$ on over-fishing. Seventy respondents were asked whether they had ever dumped refuse in or around the Keta Lagoon area. The responses show that $53 \%$ of the respondents have ever dumped refuse in and around the Keta Lagoon, while $17 \%$ have never done so. This implies that majority of the local inhabitants' dispose of their refuse in and around the Keta Lagoon which in essence, have contributed to the degrading state of the Keta Lagoon.

\section{Types of waste generated in the area}

The types of waste which were found in the area per direct observation upon visitation to the area were mainly plastic waste and organic and some fish remains. The main factors which accounted for the continuous disposal of refuse in and around the Keta Lagoon included the unavailability of waste management services in the area, the absence of landfill sites and lack of law enforcement to curtail the act. Due to the belief that wetlands are wastelands, people use the surroundings of the Keta Lagoon for the purposes of waste disposal [6-7]. This practice has been going on for a length period without any caution from the authorities to stop it. This had accumulated over the years and has been a major issue for the inhabitants. Most respondents interviewed highlighted the adverse impacts of this dilemma which would be outlined, in another section of this study. While the Keta Municipal Assembly maintains that waste management services and a communal waste container have been provided for residents, the respondents stated the contrary.

The key determinant factors, identified by the authorities as the reason for indiscriminate dumping of waste in and around the Lagoon were; ignorance, irresponsible behaviour on the part of local residents, thereby showing no form of ownership with regards to the value of the lagoon and the threats being posed to derail its significance, population increase and lack of sensitisation programs on the need to ensure good sanitation as well as seeing the lagoon as a key asset and resource thereby valuing its importance. This assertion was refuted by respondents, who stated that there were no waste management services and communal waste container provided by the authorities.

\section{Factors causing indiscriminate disposal of waste}

Factors that compelled residents around the Keta Lagoon to dump refuse in and around were identified as lack of law enforcement agencies, ignorance, inadequate facilities for waste disposal, and lack of effective waste management services. The absence of waste management services and a community landfill site for waste disposal in the area were the main reasons why the inhabitants dispose of their domestic waste in and around the lagoon. All the 70 respondents, whom the questionnaires were administered to, attested to the fact that, lack of law enforcement units, inadequate facilities for waste disposal and lack of effective waste management services were the major contributory factors to indiscriminate disposal of waste in and around the Keta Lagoon. Officials of the Keta Municipal Assembly on the other hand, attributed the factors for the continual dumping of refuse at the site to ignorance, irresponsible behaviour on the part of local residents and poor conceptualization of sanitation by the residents. They explained further that, the same people who complained about the effects of waste disposal at the site were the same people who disposed of their waste in and around the Keta Lagoon. An official at the Assembly stated that, "the people have not been enlightened or sensitized on the effects of improper disposal of waste and before any progress could be made, members of the community need to change their perception about sanitation".

\section{Environmental implications of indiscriminate dumping of waste in the area}

Inspect of environmental and social impacts, $70 \%$ of the respondents were of the view that the main environmental effects of refuse dumping in and around the Keta Lagoon was the stench smell as well as outbreak of diseases such as malaria, cholera, diarrhoea and 
typhoid, due to attraction of flies and mosquitoes from the polluted areas and hence, air and water pollution to that effect. The respondents stated that the main effect of refuse dump is the attraction of flies and mosquitoes that leads to outbreak of cholera, malaria and typhoid. Other effects mentioned by officials from KeMA include surface water contamination and soil contamination; where hazardous chemicals from the refuse leach into the soils and affect plant and animals that come in contact with such polluted soils, thus, land or soil pollution to that effect in the said area.

The study shows that the main consequences of improper waste disposal in and around the Keta Lagoon on residents are water, and air pollution, floods and health issues. Respondents stated that, after every heavy downpour, their compounds and homes were flooded with refuse or waste. It was observed that, most of the drainage systems in the area were choked with waste and sediments. Residents further mentioned that the aesthetic beauty of the Lagoon in the past contributed to the social prestige of the residents.

KeMA on the other hand emphasized on surface water contamination as the main consequence of refuse dump at the research area. One of its official stated that "wastes that end up in the lagoon negatively change the chemical composition of the water and causes water pollution". KeMA explained that people used water from the lagoon for domestic purposes in the past until waste disposal started in the area. They further mentioned that, the lagoon was now a threat to the local inhabitants who used it for domestic purposes, agriculture as well as posed serious threats to animals to animals that drunk from it with a long term adverse effects on the health status of the locals in the area [8].

\section{Socio-economic impacts of indiscriminate disposal of waste}

Some fishermen and women who were engaged in fish preservation in the area highlighted the fact that, waste in the lagoon was creating a huge problem in terms of navigation, increasing turbidity and fish market or business in the area. Fishing in the area served as the main source of livelihood for the people in the area. The sector employs a number of people, provides fish meal and nutritional value for people in and outside the Keta area. They furthered stated that, it had affected their catch or productivity and added that, market for fish in the area were declining since, inhabitants and other people who came from afar to buy from them deemed fish species from the area unhealthy for consumption in recent periods. This in essence, had affected their earnings, level of income, with most, claiming to look for other alternatives as a means of survival if the situation does not improve.

\section{General land use impact on the Keta Lagoon area}

The general land use around the Keta Lagoon area is farming and salt winning. According to the respondents, farming activities and salt winning are not effective in Keta like other neighbouring towns such as Kpedzi, Agavedzi and Adina. Respondents were asked if there were any negative impacts of farming activities and salt winning on the Keta Lagoon at Keta. All the respondents stated that, there were no negative impacts of farming and salt winning on the Keta Lagoon in the Keta community $[4,6]$.

\section{Key challenges faced by the Keta municipal assembly in the management of waste in the area}

Interviews conducted with personnel from KeMA depicted that, the assembly has plans of educating the residents on the consequence of their actions, thus the disposal of waste in the lagoon and its surrounding area. However, per direct observations upon visiting the site, no provision of a public waste bins or landing site were provided for the residents at the Keta Lagoon area. When officials were asked about the absence of a public waste bins and poor management of waste in the area, issues like;

1. Inadequacy of funds to purchase more trash bins as well as getting a refuse dumping site for the general public in some designated sites for waste disposal were one of the key issues stemming the area and assembly.

2. They also highlighted conflicts and disagreements between the assembly and traditional leaders in the area. This to a larger extent has contributed to a problem in the acquisition of land for waste management purposes thereby affecting the growth of socio-economic development in the area.

3. In addition to these, personnel from KeMA stated that, they lacked personnel and the capacity to monitor and regulate the activities of the people in managing and ensuring good sanitation in the area.

\section{Recommendations}

Based on the findings of the study, the following recommendations were made:

The government should include education on sanitation in the curriculum of basic schools so as to enable children to grow up and practice good sanitation and hygiene. In addition, the residents in the area must be sensitized on need to avoid improper disposal of waste as well as activities of fishermen being regulated to avoid more damage and possible loss of the Keta Lagoon resource.

The Keta Municipal Assembly which is in charge of waste management should provide communal waste bins at vantage points within the community for residents to dispose of their waste. These could be purchased using Assembly Common Funds allocated to them by government or by petitioning the government and private stakeholders to come to their aid.

Fishermen and fish mongers should also be educated on the negative impacts of poor fishing techniques used in harvesting, poor handling as well as preservation or storage of fish sold in the area.

Law enforcement agencies, thus, town council and sanitation inspectors under the Environmental Protection Agency (EPA) must be equipped and strengthened to ensure effective and regular monitoring of the activities of the people in the area. This in essence would regulate the activities of the people to prevent improper disposal of waste.

The Assembly could settle issues with the traditional rulers in the area, develop new schemes like; Polluter Pay Principle, where residents would pay for waste dump in a designated landfill site as well as frequent organization of communal labour to clear choked drainage systems and polluted areas in and around the lagoon.

\section{Conclusion}

Based on the findings of this study, it can be concluded that: The waste management situation around the Keta Lagoon is very bad and has both socio-economic and environmental impacts on the residents in the Keta community. The KeMA are not putting in enough effort to 
Citation: Ahmed S, Isaac S (2016) Assessing the Effects of Indiscriminate Disposal of Waste: A Case Study of the Keta Lagoon in the Volta Region of Ghana. J Biodivers Endanger Species 4: 170. doi:10.4172/2332-2543.1000170

Page 5 of 5

mitigate the impacts of poor waste management around the lagoon. The residents need to change their attitude of seeing the lagoon as a refuse dump and embrace hygienic waste disposal systems. The authority should endeavour to provide the necessary waste management services and a community landfill to help maintain good sanitation.

\section{Acknowledgement}

In the name of Allah the Lord of Aalemin (all that exist) Most Gracious, the Most Merciful, and to whom all praises and thanks are due. We wish to express our sincere gratitude to the following persons:

First and foremost, Mr Sanusi Nurudeen and Mrs Sanusi Kaosarat for their immeasurable assistance and moral support which made it possible to start this program in the first place.

Our profound gratitude also goes to the lecturers and staff of the Department of Environment and Development Studies especially $\mathrm{Mr}$ Ansu, for their immerse contribution towards this paper.

\section{References}

1. Baum B, Parker GH (1973) Solid waste disposal vol.1 incinerations and landfill. Ann Arbor Science Publishers Inc. Ann Arbor, MI. United States.

2. Ramsar Convention (1971) the convention on wetlands of International Importance, Iran.

3. Ghana Environmental Protection Agency (2004) State of Environment Report, Accra Ghana.

4. Keta Municipal Assembly (2015) Population and Housing Census report, Keta-Ghana.

5. Akyeampong EK (2001) Between the Sea and the Lagoon. Oxford: James Curreyf. 46.

6. Wetlands International (2012) Protecting the Biodiversity of West Africa.

7. Defenders of Wildlife (2014) Basic facts about Wetlands.

8. Food and Agriculture Organisation of the United States (2014) UN Millennium Ecosystem Assessment report. 